\section{Om Knabstrupperhesten og dens lød}

Afforskningsbibliotekar, cand.phil. Jesper Düring Jorgensen

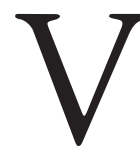
ed ordet knabstrupperhest tænker mange sikkert på en hestetype med plettet lød omtrent som en dalmatinerhund. Navnlig før i tiden kunne denne hestetype hyppigt opleves i cirkus. Men kun få udenfor knabstrupperavlernes kreds kender fortællingen om Flæbehoppen og knabstrupperhestens oprindelse.

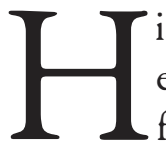
istorien handler om en hoppe med en mærkelig plettet lød. Den blev forst efterladt af en spansk officer fra den hærstyrke af spaniere, der befandt sig i Danmark i 1808 for at assistere i kampen mod englænderne og i et påtænkt forsøg på at erobre Sverige. Siden kom den via en slagter Flæbe i Holbæk til Knabstrup Hovedgaard, hvor den i en kritisk situation demonstrerede utrolig hurtighed og udholdenhed. Anekdoten går i al korthed ud på, at godsejerens søn på Knabstrup ved et fald fra et loft brækkede sit ben. Der måtte hentes læge. Den spanske hoppe og en af gårdens andre heste spændtes for en vogn, og af sted gik det til lægen, der boede $i$ landsbyen Butterup en mils vej fra Knabstrup, men lægen var ikke hjemme og måtte opledes i det noget fjernere Holbæk. Det hele udviklede sig til en længere og stærkt hasarderet køretur, der nedbrød den hjemlige hest fuldstændigt, mens den spanske hest var uberørt af turen. Alt dette - - den efterladte hest og den mageløse køretur
- er næsten for god en historie til at være sand, og forståeligt nok har mange ofte betragtet beretningen om Flæbehoppen som en blot og bar skrøne.

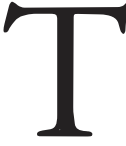

il syvende og sidst er det jo heller ikke den eneste bemærkelsesværdige fortælling, der kendes, om de heste, som spanierne efterlod i Danmark, før de af englænderne blev transporteret hjem til Spanien for at deltage i oprøret mod Napoleons broder, der var blevet indsat som spansk konge af franskmændene. I sin roman O.T. fra 1836 har H. C. Andersen udnyttet en anekdote om de hingste, som det spanske kavaleri måtte efterlade, og som blev sluppet løs udenfor Nyborg, for spanierne gik ombord i de engelske skibe: „Hvilken blændende Farve!“ udbrød Otto, i det Vennerne rullede forbi de smukke røde Blomster. „Det er en stolt Couleur!" sagde Kammerjunkeren, som reed paa sin Brune tæt ved. „En stolt Couleur! men de ere ogsaa gjødede med andalusisk Hingsteblod. Just heromkring var det Bataillen stod mellem Bæsterne! De veed, det var i 1808 Spanierne laae her i Fyen; de engelske Skibe krydsede i Beltet, og Romana med hele Hæren flygtede ombord, men deres Heste kunde de ikke faae med. Det var de prægtigste andalusiske Dyr, et Øie vilde see! de toge Tømmerne af dem og lode dem drive om her paa Marken som vilde Heste. Her græssede nu ogsaa de fra Nyborg, og da Andaluserne saae Vore, stillede de sig op i en Linie og overfaldt de danske Heste, det var en Kamp! Tilsidst sloge de hinanden selv indbyrdes, saa de styrtede i deres Blod! endnu som Dreng har jeg seet Pandeskallen af et af disse Bæster. Det er det sidste Eventyr, vi have fra Spaniernes Besøg i Danmark. " ${ }^{11)}$ Man ser, at H. C. Andersen effektfuldt har benyttet det anekdotiske stof 
som en slags tragisk pointe i sin roman.

\section{Flæbehoppen på Knabstrup}

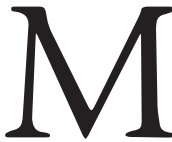

en hvorfra stammer egentligt historien om Flæbehoppen? Er det en oprindeligt mundtlig overleveret vandrehistorie, der først sent har fået skriftlig form i diverse artikler og bøger om hestevæsen i Danmark? Eller kan man spore fortællingen om Flæbehoppen tilbage i tiden til en eller anden mere eller mindre pålidelig skriftlig kilde fra samtiden, d.v.s. årene omkring napoleonskrigene? Ikke helt så langt tilbage kan man komme kildemæssigt, men omtrent.

Den første trykte redegørelse for Knabstrupperens historie fremkom i året 1855 i Tidsskrift for Veterinerer, hvor Willars Lunn, forpagter på Rønnebæksholm ved Næstved, gav en fremstilling af Knabstrupperhestens oprindelse samt en oversigt over stutteriets tilstand på Knabstrup, sådan som det var 1 . januar i 1855. Lunns artikel udkom desuden samme år som en særskilt lille bog under titlen Nogle Oplysninger om Knabstrup-Stutteriet og dets Afstamning meddelte af W. Lunn, Bangs Bogtrykkeri, Næstved 1855.

Efter hvad jeg kan se, er artiklen i Tidsskrift for Veterinarer og den lille bog de første trykte vidnesbyrd om Flæbehoppens historie og om grundlæggelsen af knabstrupperstutteriet på Knabstrup Hovedgård.

Der er ganske vist 47 år mellem Flæbehoppens opdukken i Danmark og Lunns beretning om den, men det lille halve århundrede, som Willars Lunns beretning omfatter, er måske de vigtigste år i knabstrupperhestens historie, idet hesten konstitueredes som race i denne periode, og tilmed er Willars Lunn - om end ikke grundlægger af racen - så dog søn af grundlæggeren, og han har kunnet følge udviklingen i knabstrupperstutteriet som øjenvidne.

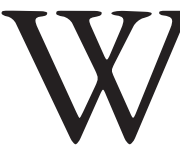

1llars Lunn er den første, der fastslår, at Flæbehoppen i 1808 blev afhændet til slagter Flæbe i Holbæk af en spansk officer. I 1812 købtes den af hans fader, Chr. Ditlev Lunn, på Knabstrup og indgik i det stutteri, som han havde opbygget $i$ årene efter 1798 . Om faderens hestebestand i dette tidsrum før Flæbehoppens opdukken på scenen fremhæver Willars Lunn tre forhold: For det første, at faderen foretrak den frederiksborgske type.

For det andet, at han yndede affarvede heste, d.v.s. lyse heste af forskellig farve, eksempelvis nævnes skimler eller gule heste. For det tredie, at han avlede efter præstation.

Willars Lunn udtrykker det således: „Ved indkjøb tog han dog ikke alene hensyn til Hestens Ydre, men han søgte gjerne at erhverve sig Hopper, der ved anstrengt Brug og strenge Herrer havde viist hvad de kunde udholde, og han har imellem casserede Ride- og kjøre-Heste fundet Tillægsdyr af stor Værdi." "2

Det var i denne avlsmæssige sammenhæng, Flæbehopppen fandt sin plads i 1812.

På en nutidig betragter virker det unægtelig inciterende at læse om en præstationsavl, der i stedet for at bygge på diverse mere eller mindre relevante afprøvninger af ungheste, havde det daglige hårde slid som udgangspunkt, og at det var kasserede ride- og køreheste, der ved vist duelighed og holdbarhed kom ind i avlen fremfor aldrig så lovende men uprøvede ungheste. Ved siden af dette praktiske, brugsmæssige aspekt kan man desuden forestille sig, at avlsdyrene sandsynligvis har 


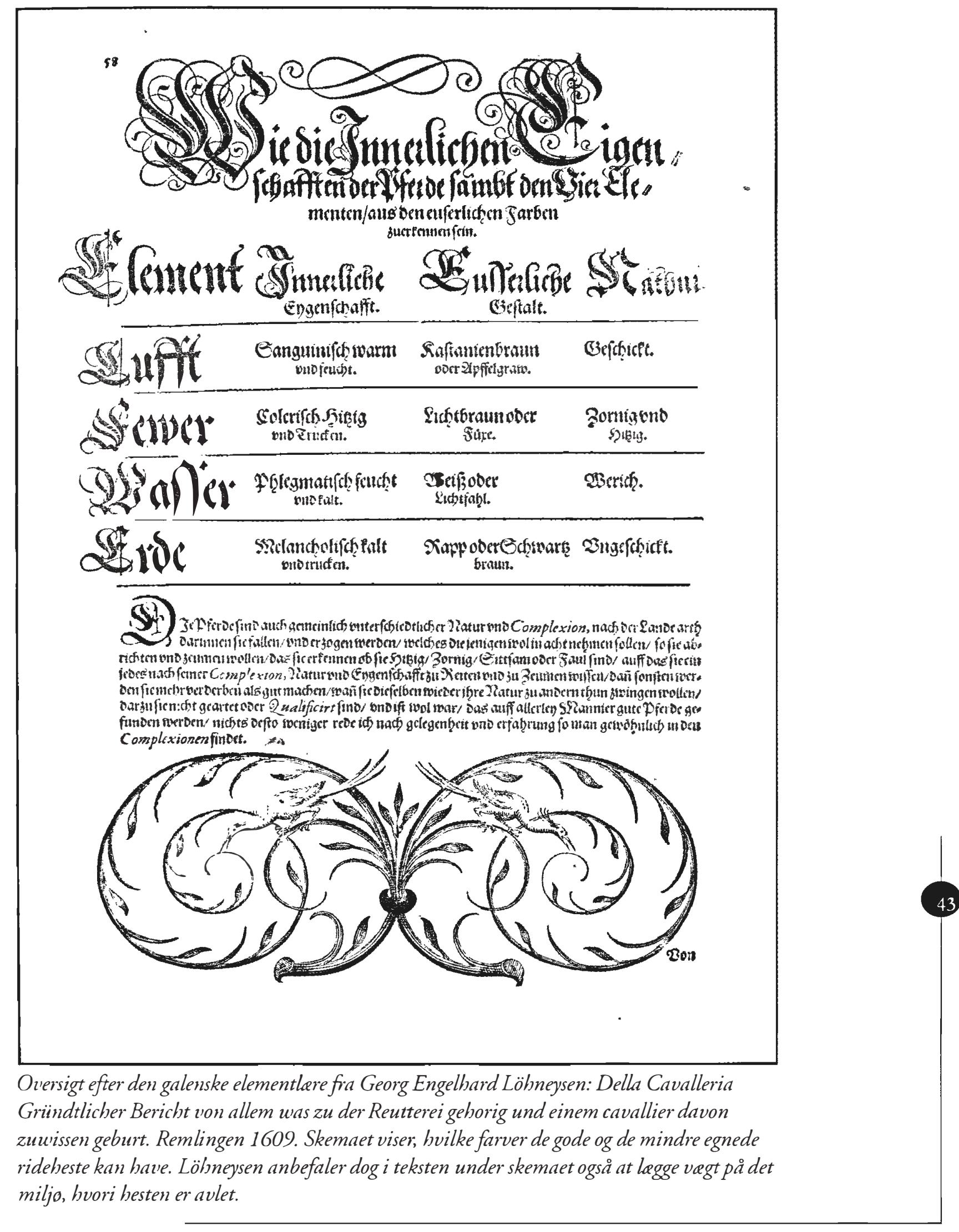


været temmelig billige i anskaffelse, eftersom de i større eller mindre omfang har været kasserede til deres oprindelige formål. Om købet af Flæbehoppen hedder det:

„Saaledes havde min Fader allerede dannet sig en temmelig eensartet heste-Familie, da han i 1812 kjøbte en Hoppe af Slagter Flæbe i Holbek, der uagtet den ikke i ydre Form aldeles svarede til de andre Heste men mere lignede en engelsk Jagthest, dog blev tilbørligen vurderet for dens mageløse Udholdenhed." (3) Videre nævner Lunn, at slagteren har købt den af adjudanten ved en spansk infanteribataljon, der blev taget til fange i Roskilde, og at hesten havde måttet yde præstationer, der kunne trodse alt væddeløb.

Det har således mere været hestens indre egenskaber end dens ydre, der har motiveret anskaffelsen af den. Den beskrives i øvrigt som en ædel, smuk hest, zobelfuchs med hvid man og hale, stærkt stikkelhåret med små hvide runde pletter hist og her på kroppen, mest på lænden, hvor der også fandtes nogle brunrøde pletter.

\section{Flæbehoppen: Spansk eller engelsk?}

$T$ sine videre forsøg på at afklare Flæbehoppens oprindelse er Willars Lunn i høj grad tvivlrådig, og man aner, at hans overvejelser må have indgået i en løbende diskussion om Flæbehoppens dunkle oprindelse. Hestens ydre særpræg, dens nedarvningsevne og hele præstationsduelighed må selvsagt have fremkaldt mange tanker herom. Lunn nægter ikke, at hesten kan være fra Spanien, men et argument herimod kunne være, at det spanske kavaleri, der var i Danmark i 1808, udelukkende havde været beredne på hingste. Men eftersom chefen for interfanteriregimentet $\mathrm{i}$ Roskilde havde kørt i en vogn trukket af fire muldyr, kunne man vel også forestille sig sandsynligheden af, at samme chefs adjudant kunne ride på en hoppe. Lunn er imidlertid mest til sinds at afvise forestillingen om, at hesten skulle stamme fra Spanien. I stedet mener han, at hoppen kom fra England. Hans argumentation herfor er, at Flæbehoppen var af en ædel og konstant race, idet hendes afkom endnu i fjerde og femte led bevarede det ejendommelige i farven. Som det fremgår af citatet ovenfor, betonede Lunn, at hoppen i form mindede om en engelsk jagthest, og det er derfor nærliggende, at han hæftede sig ved England som Flæbehoppens oprindelsessted.

$\mathrm{P}$ å samtiden har Lunns argumentation for England næppe virket tynd, men for en nutidig betragter er hans argumenter ikke overbevisende, eftersom der netop i Spanien fremfor så mange andre lande, herunder England, længe havde været avl af ædle racekonstante heste. Men Lunn er undskyldt: Hans argumentation for Flæbehoppens engelske oprindelse røber, at han i lighed med så mange andre hestekendere fra det 19. århundredes begyndelse må have været påvirket af den såkaldte "anglomani“ indenfor hesteavlen. I kort begreb var anglomanien et modefænomen, der gjorde, at man efter napoleonskrigene på det europæiske fastland ensidigt fik smag for engelske heste og engelsk ridestil. Jagtridning og væddeløb afløste tidligere tiders dyrkelse af den høje skoleridning, og følgelig forandredes de efterspurgte hestetyper gradvis. Fuldblodshesten og den engelske jagthest afløste det 18. århundredes skolehest som toneangivende og prestigegivende typer. I Danmark fik dette katastrofale følger for Frederiksborghesten, da man for at leve op til tidens idealer indkrydsede engelsk 
fuldblod, men det er en ganske anden sag, som vi vil lade ligge her.

Det er meget sandsynligt, at Flæbehoppen kan have mindet om en engelsk jagthest, men det er også lige så sandsynligt, at Willars Lunn i den fremmede hest har set det, han netop har ønsket at se, og helt i tidens ånd har det været en engelsk hest. Der findes næppe noget billede af Flæbehoppen, og derfor er vi afskåret fra en nærmere bedømmelse af rimeligheden $\mathrm{i}$ hans beskrivelse af hesten.

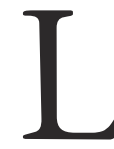

unns beretning blev gennem de efterfølgende år hyppigt citeret, og specielt hans bestemmelse af

Flæbehoppen som stammende fra England blev drøftet.

\section{Ugeskrift for Landmand, 2. Rk.} bd. 1, s. 107 tog en kammerråd J. B. H. Andersen afstand fra Flæbehoppens cngelske oprindelse med disse ord:

„At Hoppen, som Nogle antage, skulde være af engelsk Oprindelse, betvivler jeg af flere Grunde, og navnlig fordi det særegne Lød, som den ene saa bestemt har nedarvet i sin Slægt, og som ikke sjælden endog i 4de Led aldeles bestemt er fremkommen, viser, at Hoppen har været af et konstant hesteslag med dette Lød, og som næppe i England kunde være sporløst forsvunden. Det forekommer mig derfor rimeligere, at Hoppen er medbragt direkte fra Spanien og vel saa har været andalusisk eller, hvad man vel lige saa godt kan sige, af orientalsk Oprindelse."

En senere tids iagttagelser har haft til følge, at man i dag er mere tilbøjelig til at følge kammerråd Andersens ræsonnement, og med større sandsynlighed placerer man i dag Flæbehoppens hjemsted i Andalusien.

\section{Den moderne knabstrupperhest} grundlægges

$\mathrm{M}$ en en race grundlægges jo ikke af en enkelt hoppe. Som vi har set, var Flæbehoppen et tillæg til en

eksisterende avl af heste af frederiksborgtype. Overfladisk set så dansk en avl som nogen og så fjernt fra Spanien og Andalusien som vel muligt. Men afstanden er i dette tilfælde ikke så stor endda. Man skal huske på, at en væsentlig basis i Frederiksborgstutteriet blev lagt netop med spanske heste gennem 1500 og 1600-årene, en periode, hvor spanske heste dominerede i Europas hofstutterier.

Efter erhvervelsen i 1812 blev Flæbehoppen bedækket med en hingst fra stutteriet på det nærliggende Løvenborg, hvis hestebestand var en aflægger af Det kongelige Frederiksborgstutteri. Denne hingst, der beskrives som gul med hvid man og hale, var en efterkommer af den navnkundige frederiksborghingst Bæver 2, født på Frederiksborgstutteriet i 1782 i syvende led af den røde stamme. Denne stamme kan føres tilbage til en sort hingst fra Spanien, som antageligt fødtes i 1683, samt til den røde hingst Agreable, født 1696. Fra ca. 1700 var den røde farve ganske vist dominerende, men ikke enerådende i stammen. Heste med andre farver forekom.

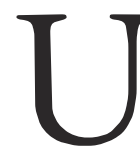

$$
\begin{aligned}
& \text { nder alle omstændigheder kan man } \\
& \text { fra tiåret } 1716 \text { - } 1726 \text { via } \\
& \text { Agreables datter, Hjerte, der }
\end{aligned}
$$

beskrives som gultigret, følge den gule samt den tigrede eller plettede farves indgang $\mathrm{i}$ den røde Frederiksborgstamme, og det er sandsynligvis herfra, den gule hingst på Løvenborg har fået sin smukke gule lød, der desværre kun alt for sjældent dukker op på nutidens knabstruppere. Mødet mellem Flæbehoppen og den gule hingst fra Løvenborg var således ikke et møde mellem 


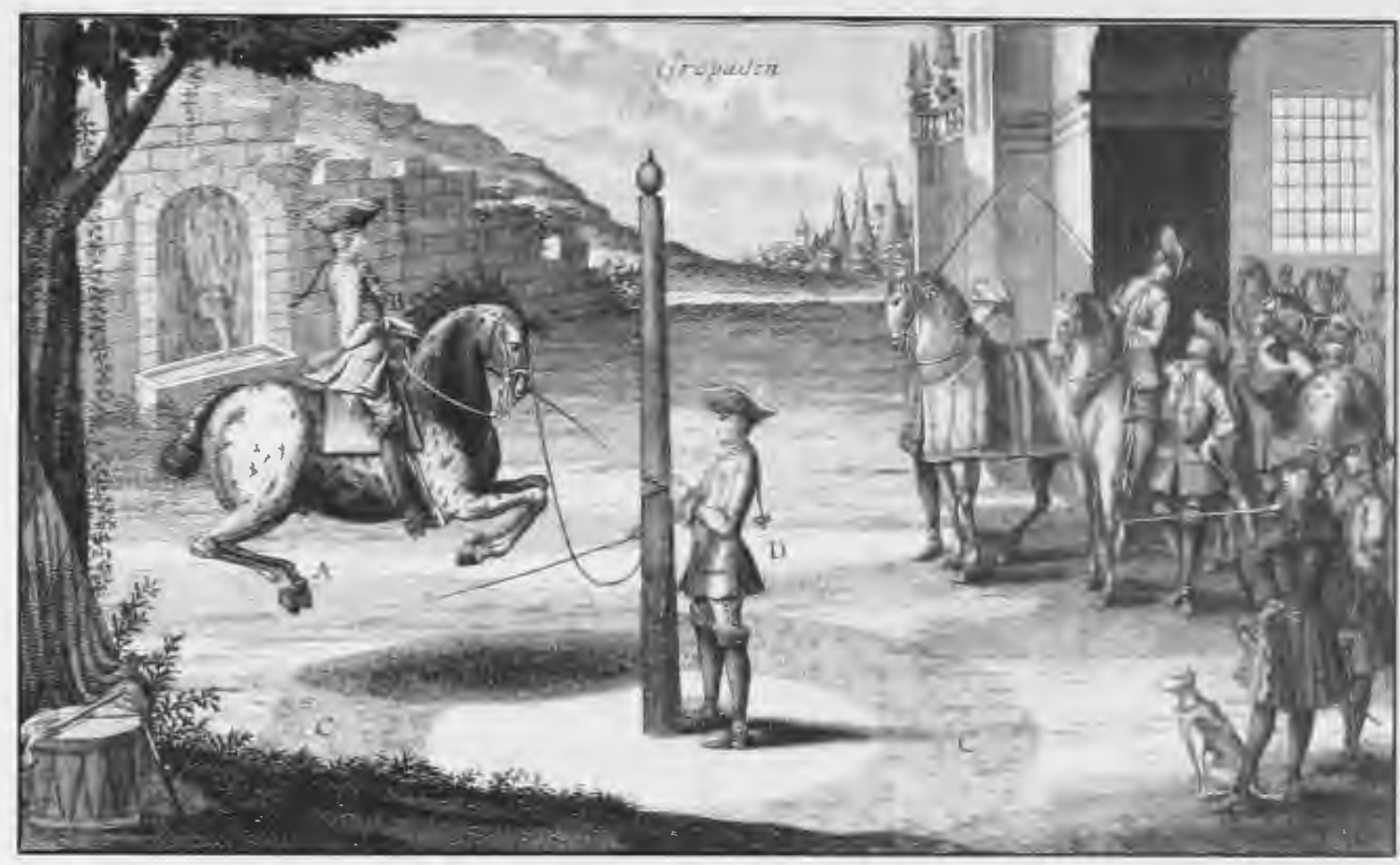

Groupade vist ved pilaren af rytter på en tigret hest. I Löhneysens rideboger fra 1609-10, der med sandsynlighed var illustreret afforfatteren selv, findes ingen tigrede eller spattede heste på illustrationerne, men på den udgave, der kom i 1729 findes adskillige. Et eksempel på modens omskiftelighed i hesteavlen. (Illustration fra Georg Engelhard Löhneysen: Neu-eröffnete Hof-Kriegsund Reitschul. Nürnberg 1729).

en dansk og en spansk modsætning, men snarere en forstærkning af visse fælles gener, der sandsynligvis har haft en fælles oprindelse i Spanien. Bedækningen af Flæbehoppen resulterede 1813 i en spættet hingst, der efter sigende skal have haft 22 forskellige farver. Hingsten fik navnet Mikkel, og efter den er knabstrupperne også siden blevet betegnet som "mikkeler“. Desværre er denne hingst næppe nogensinde blevet malet eller tegnet, og vi kan derfor kun gisne om dens type og udseende, hvilket er ærgerligt, da man med nogen ret kan betragte den som stamfaderen til den moderne knabstrupperhest. Sin udholdenhed og hurtighed syntes den at have overtaget efter moderen, men man skal ikke være blind for, at også Bæverhestene i det 19. århundredes begyndelse gjaldt for at høre til Frederiksborgstutteriets mest værdifulde del, idet disse heste ikke i samme grad som stutteriets øvrige bestand var præget af den degeneration, der i 1800 tallet ramte stutteriet så fatalt. Med stolthed beretter Willars I unn om, hvorledes Mikkel umiddelbart efter en køretur fra Knabstrup til Slagelse væddeløbsbane var i stand til at vinde væddeløbet for derpå at returnere til Knabstrup endnu samme dag. Men Mikkel har formentlig også fået en del gode egenskaber og farveanlæg fra sine frederiksborgske aner.

\section{Farven på de forste knabstruppere}

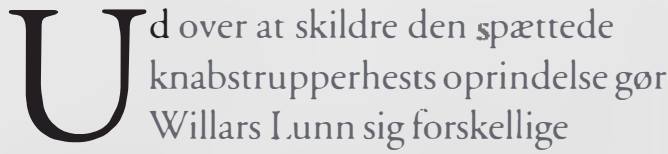

overvejelser angående den specielle spættede 
lød samt hestetypens karakteristika i øvrigt. Sagen var nemlig, at tigrede eller spættede heste på Lunns tid for længst var blevet umoderne. Da de spættede eller tigrede farver dukkede op i Chr. Ditlev Lunns avl, var årsagen dels hans personlige - og i virkeligheden atypiske - interesse for affarvede, d.v.s. skimlede eller blakkede hestetyper, dels det historisk set tilfældige sammentræf af anlæg for pletter, som både Flæbehoppen og den gule bæverhingst har været bærere af.

Willars Lunn nævner i sit skrift, at man i disse første årtier af knabstrupperavlen faktisk kritiseredes for farven, bl.a. i en rapport, som konstitueret landstutmester Dr. G. E. With udarbejdede for året 1851 .

Ganske vist rådede With til at bruge knabstrupperheste som forædlere af hesteavlen i Holbæk Amt, men som noget negativt anførte han følgende helt i tidens ånd.: „Mod at afbenytte Heste af Knabstrupper Racen til Avl, kan det indvendes, at de ere tilbøielige til at give et spettet Afkom - hverken den ægte tigrede eller brogede Farve; - men de ere i Besiddelse af saa mange andre Dyder, saavel med Hensyn til deres meget forædlede Præg, som øvrige gode Beskaffenhed, at de paagjældende ikke alene selv kunne bruge dem med Fordeel, men ved given lejlighed let kunne sælge dem paa fordeelagtig Maade. " ${ }^{(t)}$ Forsøg på at bortavle denne utidssvarende lød havde man dog ikke meget held med. Hertil kom, at man mente at kunne iagttage, at hestens ovrige gode egenskaber tabtes i samme takt, som den karakteristiske farve udviskedes.

Man kan have sin tvivl om den objektive sandhed i denne iagttagelse, men under alle omstændigheder ophørte man med bestræbelserne på at lade farven forsvinde. Farven måtte man tage med. I - begyndelsen som et nødvendigt onde, siden gjorde man åbenbart en dyd af nødvendigheden, idet det synes som om knabstrupperens farve - selv i denne tid med andre idealer for hestefarver - alligevel blev ganske eftertragtet, måske nok så meget, fordi man troede, at den spættede lød var en garanti for den gode hest. I Lunns formulering lød det således: „... thi uafset fra at det spettede Lød for Tiden endog synes at være i Mode, saa ere Knabstrupperhestene nu saa anerkjendte for deres Udholdenhed, at selv naar Moden slaaer om, ville Hestene dog staae høit i Handel og Vandel formedelst deres mange gode Egenskaber." (5)

Man måtte således kapitulere overfor de hårdnakkede farvegener.

raditionelt betegnes en hest med
hvidt skind og pletter i en anden
farve jævnt fordelt over hele kroppen som en tigret hest, mens en hest med mere eller mindre ensfarvet forpart og plettet lænd og kryds betegnes som en skaberaktigret hest - eller hvis farvevariationerne er vanskelige at beskrive entydigt, bruges betegnelsen spættet, ganske som Lunn gør det i sit skrift.

I følge den stutterioversigt, hvormed Willars Lunn afslutter sin artikel, er vi i den heldige situation, at vi - ud over at få en opgørelse af hingste, hopper og afkom - også făr en oversigt over de farver, der var repræsenteret i stutteriet anno 1855 . Den første januar dette år rummede stutteriet $\mathrm{i}$ alt 39 heste, således specificeret: Hingste: to. Hoppebestand: 16. Af ungheste fandtes 21. Heraf var 13 to- eller tre-årsplage, nemlig seks hingsteplage, syv hoppeplage samt otte føl. Alt i alt ikke nogen stor bestand i racemæssig henseende, men til gengæld et anseeligt privatstutteri, og sandsynligvis har det udgjort den største 
samlede bestand af knabstruppere på denne tid. Ved siden af opgørelsen over bestanden på Knabstrup anfører Lunn syv hingste, hvoraf kun to, Frode og Thor, tilhørte stutteriet på Knabstrup, mens de resterende fem havde andre ejere. Alle syv betegnedes som indbrændt som stutteridygtige. Herved får man et relativt begreb om spredningen af hestene samt et indicium for, at man på dette tidspunkt åbenbart også drev avl på en foreningslignende måde. Bedømt ud fra ejernes navne og stillingsbetegnelser ser det ud til, at knabstrupperhestene på dette tidspunkt fortrinsvis fandtes på det større landbrug.

\section{Med hensyn til farverne på de} opgivne dyr ser det unægtelig ud til, at den tigrede knabstrupperhest på dette tidspunkt har været temmelig sjælden. Af de 39 heste betegnes kun hingsten Frode som bruntigret, mens 16 dyr betegnes som spættede. Fire betegnes som gule med hvid man og hale, en enkelt som gul med sort man og hale. Endnu en enkelt af de gule betegnedes lidet flatterende „skidengul“. De øvrige syv ensfarvede heste var brune eller røde, men nok så interessant er det, at der endnu på dette tidspunkt kan registreres tre dyr, der formentlig har ligget tæt på stammoderen i farve. De betegnes nemlig som værende „zobelfuchse“ med hvid man.

Det er interessant at se, at datidens knabstruppere på Knabstrup Hovedgaard farvemæssigt har adskilt sig fra nutidens på den måde, at den nu om dage så eftertragtede og langt hyppigere forekommende tigrede farve bestemt ikke var dominerende på stutteriet på Knabstrup, mens den mere uvisse spættede lød til gengæld var fremherskende.

Om grunden hertil kan man naturligvis kun gisne, men et nærliggende bud er, at man i datiden nok så farverne - den spættede eller den tigrede - som et interessant kuriosum, men ikke som et specielt eftertragtet avlsmål, sådan som det siden er blevet tilfældet.

I disse første årtier af knabstrupperavlen fik man ved et lune af naturen og ved en historisk tilfældighed spillet en hestetype i hænderne, der ud over disse i tiden sjældne farver også rummede efterspurgte brugskvaliteter. Willars Lunn udtrykte således: „Hestene af Knabstrup Racen kunne anvendes baade som Rideheste for Herrer og Cavallerister, og som Kjøreheste, saavel Karethheste, som til Postog Arbejdsheste; hvilket Fortrin ingensomhelst anden forædlet Race i den Grad er i Besiddelse af." "(6)

Hestens lød i kulturhistorisk perspektiv

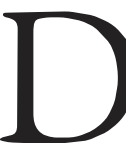
et hedder nok så dydsiret, at god hest ingen farve har. M.a.o. hestens indre, brugsmæssige egenskaber er det afgørende uanset hestens lød, men hestenes farver; fordommene - eller den høje mening - om dem har alligevel altid spillet en vigtig rolle i skiftende tiders bedømmelse af heste. I virkeligheden har hestefarverne en egen mini-kulturhistorie, som næppe mange kender, og når man beskæftiger sig med en historisk hestetype som knabstrupperen, er det kun naturligt at se den karakteristiske knabstrupperlød i en historisk sammenhæng. Fra 1500-tallets midte, med opblomstringen af den trykte ridebog, har vi nogenlunde pålidelige kilder om den rolle, som hestens farve spillede.

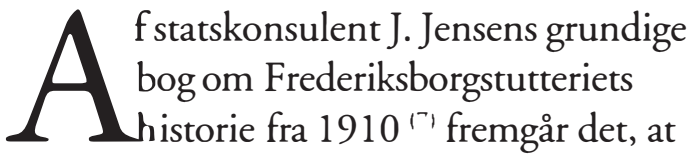
man på dette stutteri i en lang periode opdelte hestene efter farve i givne stod, d.v.s. et antal hopper samt en hingst. Faktisk fandt 


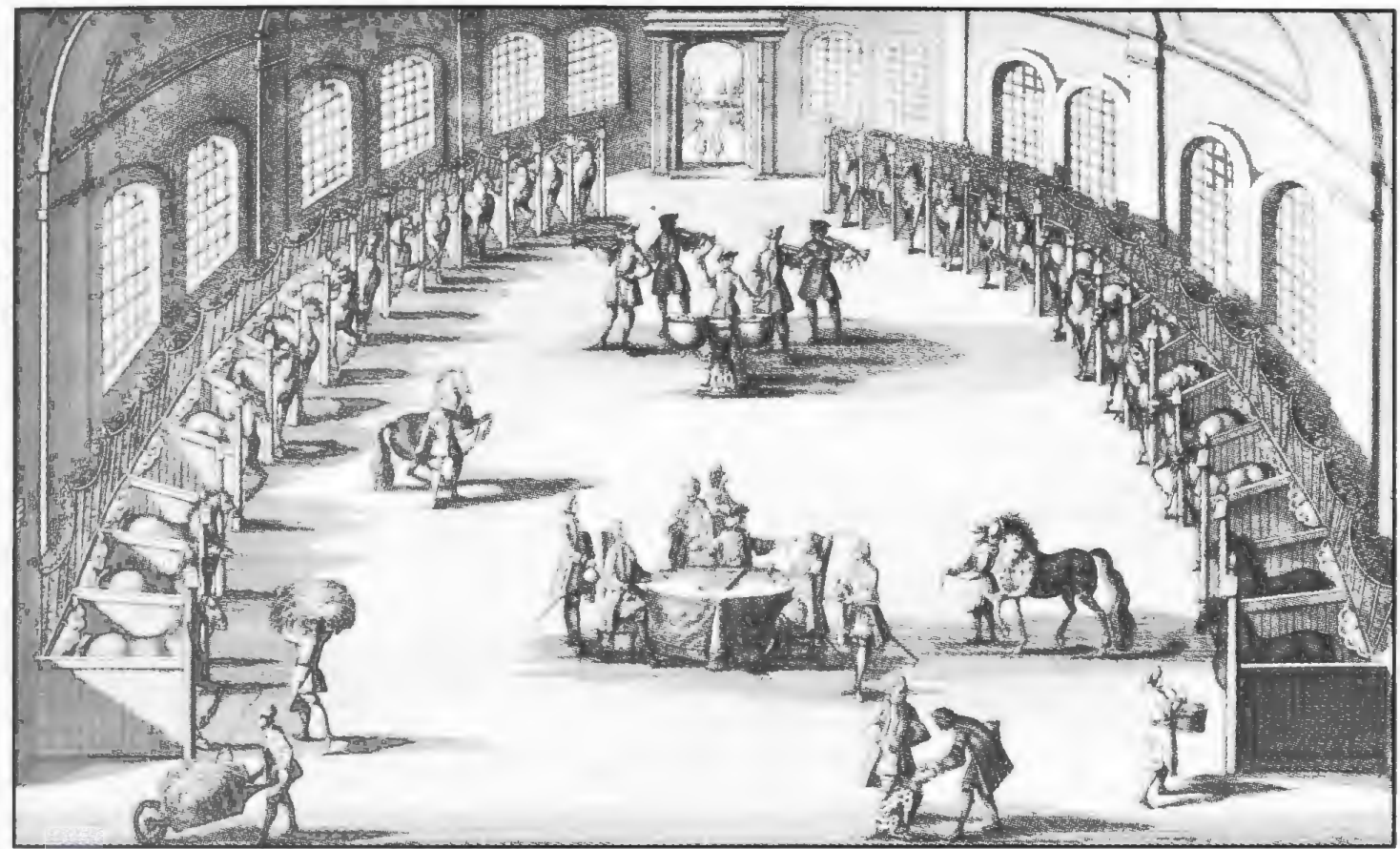

Staldinterior med tigrede heste og en dalmatiner/und fia Cieorg Engelhard I.jolmeysen: Nenerioffinete Hof-Kriegs-und Reitschul. Niumberg 1729.

bogens forfatter heri et klart vidneshyrd om den tids planloshed i hestcavlen, men han skal vare undskyldt. Selv om J. Jensen sikkert har varet en kompetent avlskonsulent og desuden også ganske dreven til at soge kilder i arkiverne, er det til gengadd klart, at han ikke har haft nogen dybere viden om den tankegang, der på et overordnet plan var bestemmende for hesteavlen i axldre tid.

I. Jensen var landbrugets mand. I sin bog vurderer han ensidigt hesteavlen i 1) anmark ud fra de interesser og behov, landbruget havde på hans egen tid, og demne synswinkel, der tydeligvis er et resultat af den selvbevidsthed, som pragede den danske bondestand $\mathrm{i}$ årene omkring systemskiftet, levner ikke megen forståelse for den oprindelige Frederikstorghest, endsige sympati for den statslige avl af hoffets ogaristokratiets skolehest.

Det at opdele en hestebestand - efter farve var alt andet end udtryk for planloshed. Tankegangen bag denne systematik var mindst lige så dybsindig, og ud fra tidens forestillinger lige si videnskabeligt velbegrundet, som vore dages opfattelse af geneme og deres virkemaide.

I hestefarverne havde man et særedeles synligt udtryk for det, man på andre omräder af menneske- og kulturlivet har betegnet som den aristoteliske verdensopfattelse.

Aristoteles' filosofi var et forsog påa at opstille et filosofisk helhedssystem påa grundlag af et stort systematisk bearbejdet erfaringsmateriale, hvor laeren om de fire elementer, jord, vand, luft og ild, blev betragtet som de afgorende grundstoffer for alt liv. Med laxgen (ialen, der levede fra 129 til 19), kombineredes teorien om de fire clementer med laxen om de fire legemsvæesker, blod, slim, de'n gule galde og den sorte galde. Ud fra tilstedeverelsen af disse væsker forklaredes igen de fire temperamenter, man mente at kunne iagttage hos 
jordens skabninger: Det sangvinske, det flegmatiske, det koleriske og det melankolske. Galens tankegang blev på mange områder ført videre gennem middelalderen og renæssancen, ikke mindst hans teori om de fire elementers indflydelse på menneskets legeme og sjæl.

I flg. Galen havde ild, vand, luft og jord hver $\sin$ fremherskende egenskab, nemlig henholdsvis varme, fugtighed, tørhed og kulde. I den ene legemsvæske, blodet, fandtes de fire legemsvæsker i ligelig eller harmonisk blanding, mens vandet dominerede i slimen, ilden i den gule galde og jorden i den sorte galde. Ved sammensætningen af elementernes kvaliteter opstod en række egenskaber ved organismen såsom varme, kulde, grad af fugtighed o.s.v., ligesom forskellig smag forklaredes ved forskellige sammensætninger af legemsvæskerne. I sidste ende gav blandingen af legemsvæskerne sig udslag i temperamentet, hvor man skelnede mellem fire forskellige, alt efter hvilken legemsvæske der dominerede: Eksempelvis beroede det koleriske temperament på den gule galdes overvægt i legemet, det flegmatiske på slimens dominans, det melankolske på den sorte galdes og det sangvinske på blodets.

I virkeligheden var denne lære om de fire elementer som byggesten for alt liv et storslået forsøg på at etablere en harmonilære, forstået på den måde, at det afgørende for det gode temperament og de gode egenskaber var den rette harmoni mellem elementerne og legemsvæskerne.

\section{Farven som en faktor for hestens} temperament

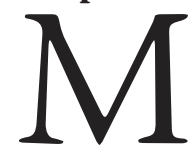
en hvad har nu alt det med hesteavl og hestefarver at gøre? Faktisk ganske meget.
I 1500- og 1600-årene betragtede man hestens lød som en slags afspejling af dens temperament og indre egenskaber. Hos en af renæssancens største hippologer, Georg Engelhard Löhneysen, der virkede som staldmester for hertugen af Wolfenbüttel Lüneburg fra 1583 til 1622, - og for øvrigt også for den danske konge Frederik II. fra 1586, - vil man se, at han i sit tobindsværk om ridekunst og hesteavl: Della Cavalleria Gründtlicher Bericht von allem was zu der Reuttereigehörig und einem cavallier zuuissen geburt, Remlingen 1609 og Grïndtlicher Bericht vom Zeumen und ordentliche Ausstheilungen der Mundstïck und Stangen..., Remlingen 1610 ligefrem har et stort kapitel, hvor han ud fra den galenske harmonilære forsøger at opstille en systematik i skemaform over, hvilke hestefarver og hvilke temperamenter, der er at foretrække ud fra rytterens synsvinkel.

Betegnende nok foretrak Löhneysen langt brune eller æblegrå heste som den type, der havde det mest harmoniske temperament, hvor det sangvinske og det flegmatiske stod i et sådant forhold, at man som udgangspunkt fik den fyrige, gode og let afrettelige ridehest. Men hvordan så man nu på den spættede eller den tigrede lød på Löhneysens tid?

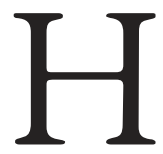
vor nødigt jeg end må indrømme det: Löhneysen - og tilmed har han formentligt blot udtrykt sin tids gængse opfattelse - brød sig ikke om flerfarvede eller blakkede heste. Han nævner ikke tigrede heste direkte, men disse typer sammenfattede han under betegnelsen: Heste med urene farver; og hvor disse dominerede var Löhneysen tilbøjelig til at betragte hestene som værende uden energi og nerve.

Den væske, der dominerede i 
disse dyr, var jo blot slimet. Ser man tillige på billeder af heste fra denne periode, vil man se, at der ikke i 1600-tallets første halvdel forekommer billeder af tigrede eller spættede heste. Mon ikke forklaringen på det kunne være udtryk for elementlærens indflydelse på hesteavlen? På baggrund heraf var helt naturligt avlsmæssigt at sortere sine stod efter farve, idet man naturligvis ønskede at tilføre sin avl den rigtige balance af

legemsvæskerne, således at man kunne være så sikker som mulig på, at hestenes temperament var så godt som muligt. Men

Löhneysen var ikke alene bundet af denne middelalderlige tankegang med dens dybe rodder i den klassiske oldtid, han var desuden en praktisk iagttager af naturen, og derforopfordrede han tillige til, at man også lagde vægt på det miljø eller de omgivelser, hvorfra hesten stammede, idet disse forhold også spillede en væsentlig rolle for avlen.

\section{Vekslende mode i spættede og tigrede} heste

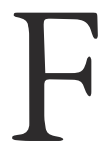
ra 1600-tallets sidste halvdel og gennem forste halvdel af 1700-årene synes forholdet at ændre sig. Indenfor medicin og filosofi i denne periode viger den aristoteliske elementlære til fordel for mere moderne filosofiske og empirisk prægede opfattelser, der i højere grad byggede på eksakte erfaringer fremfor på spekulative systemer, og det er da en nærliggende tanke, at forestillingerne om hestefarvernes betydning i relation til hestens temperament og øvrige egenskaber efterhånden tabte sig. Alligevel vedblev man også i denne periode på hofstutterierne rent mekanisk at opdele hestene i stod efter farve, måske mere et udtryk for traditionens sejlivethed end for en tro på elementlæren. Under alle omstændigheder kan det

- konstateres, at de tigrede og spættede heste kommer i mode i de to-tre sidste årtier af 1600-tallet, og at denne interesse for de brogede og tigrede heste holder sig til omkring 1770, hvis man skal dømme efter tidens billedlige fremstillinger i malerkunsten og i ridelitteraturen fra denne epoke. Naturligvis hører det med i billedet, at der også i denne periode på Det kongelige Frederiksborgstutteri fandtes tigrede heste. I midten af 1745 oprettedes der ligefrem et tigret stod, der var levedygtigt til 1759.

Tigrede og spættede heste findes gengivet i næsten alle denne tidsalders ridebøger, og der findes ligeledes utallige malerier af tigrede heste fra disse år. Tænk bare på den fine billedserie med fremstilling af karruselscener og eksempler på skoleøvelser på Rosenborg Slot fra Christian V's tid, eller på de noget senere billeder i England på Wilton House. I begge billedserier findes flere tigrede heste. I serien på Wilton House er en af dem tilmed betegnet som en dansk hest. Slår man op i 1700årenes standard-rideværk, Guérinières berømte ridebog Ecole de Cavalérie Contenant la Connoissance l'instruction et la Conservation du Cheval, Paris 1733, vil man støde på prægtige kobberstik af spættede og tigrede heste bogen igennem.

Men henimod 1700-årenes

slutning synes interessen igen at svinge over til fordel for de ensfarvede hestetyper, og efter napoleonskrigene, hvor ridekunsten på det europæiske kontinent forandrede sig radikalt, blev denne tendens så at sige enerådende. Engelske heste og engelsk ridestil blev fuldstændig dominerende i Europa. Tigrede eller spættede heste blev umoderne. De havde haft deres storhedstid i senbarokkens og rokokotidens farvestrålende optog og karruseller ved de hofrideskoler, der fandtes ved så at sige ethvert fyrstehof i Europa. Men i de magre år efter 
napoleonskrigene, - i Danmark var der statsbankerot, og i siden stødte en dyb landbrugskrise til, - kom fyrstehofferne overalt i Europa under både politisk og økonomisk pres, og den ekstravagante, økonomisk krævende skole- eller manégeridning forsvandt de fleste steder på det europæiske fastland.

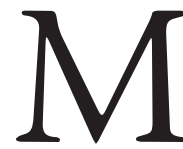
ed det opadstigende borgerskabs indflydelse fulgte en afdæmp ning i levemåde, klædedragt og livsstil. Aristokraten afløstes som trentssætter, først af biedermeyeren, senere i århundredet af den victorianske gentleman, og ridekunst blev til ridesport. Den ensfarvede, gerne brune hest kom igen i mode, som den havde været det i 1500-tallet, men denne gang uden skygge af nogen filosofisk-biologisk begrundelse i elementlæren. Måske snarere som følge af den usikkerhed, der altid følger den, der stiger socialt: På den ene side er der et behov for at demonstrere den nye fremragende status, på den anden en betydelig ængstelse for at blamere sig, og $\mathrm{i}$ denne usikre, modsigelsesfyldte situation har den ensfarvede hest kunnet virke som et kompromis, der dels kunne tilfredsstille trangen til "blær" og dels sikre, at man ikke kom til at virke afvigende i den gruppe, hvor man ønskede at gøre den gode figur med sin hest og ridning. Interessen for ridning og heste er jo på en gang knyttet tæt til pengemarkedet og mindst lige så intimt til forfængelighedens marked.

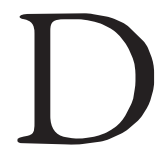
a knabstrupperhesten konstituere des som race i det 19 . århundredes første halvdel, var der i virkeligheden tale om et højst utypisk fænomen i tiden, og man forsøgte da også af ærligt hjerte at blive den spættede lød kvit, men uden held. Til gengæld betød hestenes meget gode kvalitet i denne periode, at farven fra at have været et nødvendigt onde blev et signal om, at man med en spættet eller tigret hest også stod overfor en god hest, og herved opstod paradoksalt nok en slags sub- eller kultmode på tværs af tidens konventioner. Knabstrupperhestens første historiker, Willars Lunn, holdt ikke af situationen og karakteriserede den således: „Da Heste med et Lød som Knabstrupperne synes at være i Mode, saa er mangen En meget tilbøielig til at ansee enhver spettet Hest for en god Hest; og det er desværre at befrygte, at denne Mode vil virke skadelig paa den Anseelse, som Racen nu for Tiden staaer i, da mangen en Liebhaver betaler Skindet med høi Priis istedetfor Hesten; og, naar han føler sig skuffet, kaster han med Urette Skylden paa Racen." ${ }^{(x)}$ Lunn rammer uden tvivl fuldstændig plet med denne korte, skeptiske redegørelse for modens psykologi og den rolle den synes at spille i hesteavlen til hver en tid.

Noter

1. H.C. Andersen: O.T., udgivet af Mogens

Brønsted s. 51-52, DSL. Borgens Forlag 1987

2. W. Lunn: Nogle Oplysninger om KinabstrupStutteriet og dets Afstamning, Næstved 1855.

$=$ Lunn, s.11

3. Lunn, s. 12

4. Lunn, s. 3-4

5. Lunn, s.5

6. Lunn, s. 9

7. J. Jensen: Det kongelige Frederiksborgske Stutteri, 1910.

8. Lunn, s. 5 